\title{
Understanding the Biodiversity Contributions of Small Protected Areas Presents Many Challenges
}

\author{
Robert F. Baldwin * and Nakisha T. Fouch \\ Department of Forestry and Environmental Conservation, Clemson University, Clemson, SC 29634, USA; \\ nfouch@g.clemson.edu \\ * Correspondence: baldwi6@clemson.edu; Tel.: +1-864-656-1976
}

Received: 27 September 2018; Accepted: 18 October 2018; Published: 20 October 2018

\begin{abstract}
Small protected areas dominate some databases and are common features of landscapes, yet their accumulated contributions to biodiversity conservation are not well known. Small areas may contribute to global biodiversity conservation through matrix habitat improvement, connectivity, and preservation of localized ecosystems, but there is relatively little literature regarding this. We review one database showing that the average size of nearly 200,000 protected areas in the United States is $\sim 2000$ ha and the median is $\sim 20$ ha, and that small areas are by far the most frequent. Overall, $95 \%$ and $49 \%$ of the records are less than the mean (1648 ha) and median (16 ha), respectively. We show that small areas are prevalent features of landscapes, and review literature suggesting how they should be studied and managed at multiple scales. Applying systematic conservation planning in a spatially hierarchical manner has been suggested by others and could help insure that small, local projects contribute to global goals. However, there are data and financial limitations. While some local groups practice ecosystem management and conservation planning, they will likely continue to protect what is "near and dear" and meet site-based goals unless there is better coordination and sharing of resources by larger organizations.
\end{abstract}

Keywords: conservation landscapes; scale of assessment; conservation planning

\section{Introduction}

There is wide agreement that the biodiversity crisis is best met with a carefully planned system of large conservation areas within well-connected networks [1]. However, humanity did not act in a concerted, globally-minded fashion to produce a functional system that protects biodiversity. Rather, what exists on the landscape is a distribution of conserved parcels with histories related as much to aesthetics and socioeconomic convenience as to systematic scientific goals [2,3].

There has been much research examining the effectiveness of the protected areas' estate. There is a preponderance of literature concluding that protected areas' coverage is inadequate, spatial distributions are biased, edge effects are eroding interior conditions, and that there is poor governance resulting in alienation of local human populations [4-6]. There is less understanding of how these negative conditions might be ameliorated by very local actions, resulting in a matrix of improved landscape conditions and more engaged conservation constituents [7,8]. An area of research that needs attention is the landscape-level function and roles played by the plethora of very small protected areas, although marine protected areas have received more attention [9]. In fact, there is little descriptive information revealing the dominance by frequency across the land surface of small areas. To that end, we will briefly review one dataset-the Protected Areas Database of the United States-as to size distributions, and then discuss broader conservation issues concerning small areas. Throughout, we make recommendations for further research. 
The Protected Areas Database of the United States V1.4 (PADUS) has 194,518 parcels for the continental US, including designations as local as county parks and conservation easements, as well as large national parks and forests [10]. The PADUS is maintained by the United States Geological Survey's National Gap Analysis Project in order to organize and assess the management status of elements of biodiversity projection, i.e., "protected areas". The database includes all known public areas and voluntarily provided, private protected areas (e.g., conservation easements). The PADUS has versions between 2005 and 2016, currently at V1.4 (https://gapanalysis.usgs.gov/padus/data/metadata/).

We derived simple summary statistics of the PADUS area attributes and displayed them. The median area of parcels in the PADUS was 16 ha, the mean was 1648 ha $(S D=33,207.1)$, and the frequency distribution is skewed strongly right (Figure 1). Small areas were nonuniformly distributed but present in every major ecoregion (Figure 2). There are 95,116 parcels $<16$ ha and $185,751<1648$ ha in size, representing $49 \%$ and $95 \%$ of the count, respectively. However much they dominated by count, the smallest areas ( $<16$ ha) and those $<1648$ ha represented $0.13 \%$ and $4 \%$ of the total area, respectively. Acknowledging possible errors of omission and commission in the dataset (see below), these descriptive analyses serve to illustrate the point that while the area covered is dominated by largeness, by number, most areas are not large. This presents unique research and management problems.

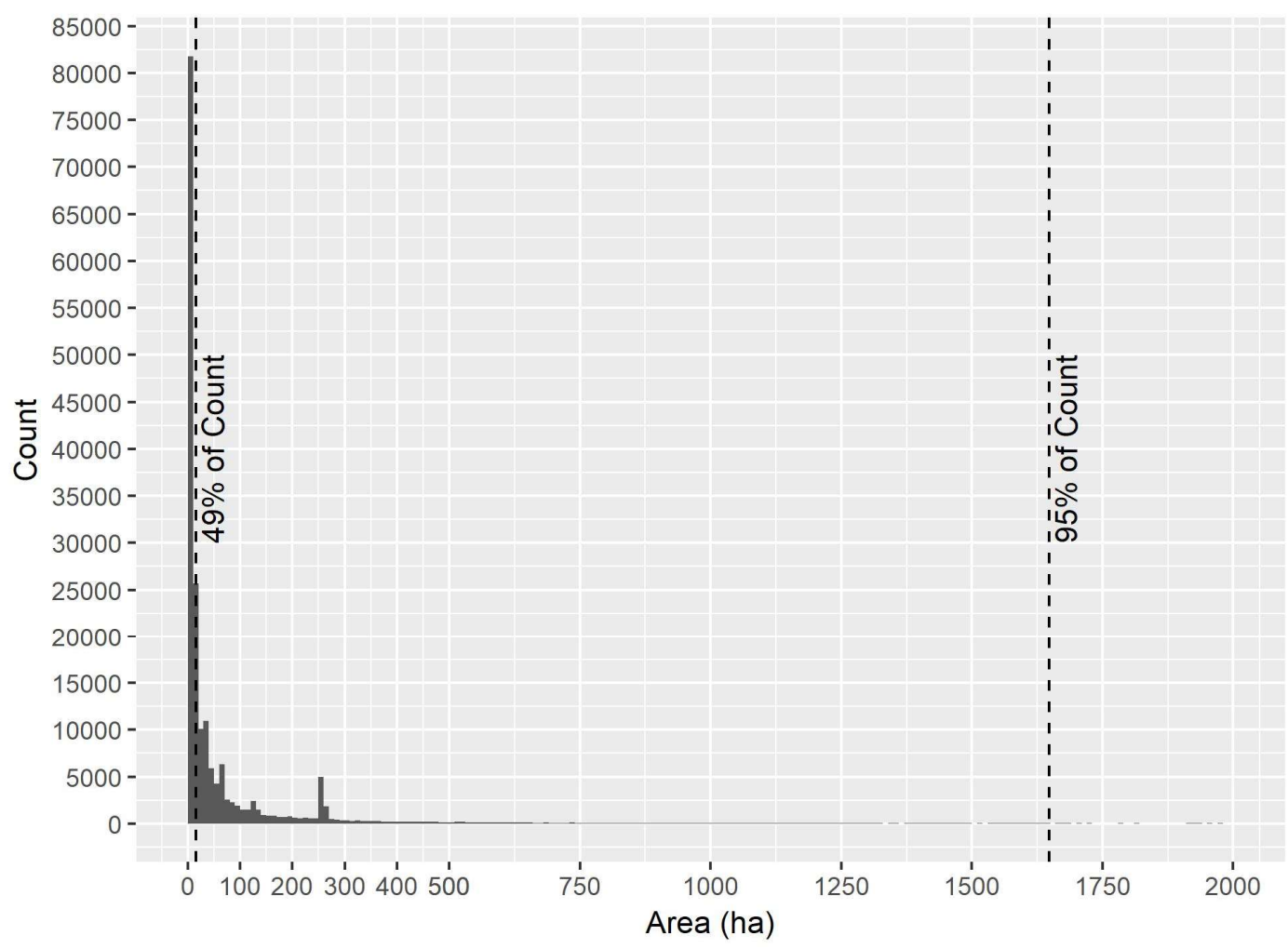

Figure 1. Frequency distribution of protected area parcel sizes in the United States. The $x$ axis is truncated at 2000 ha in order to show the distribution on the $y$ axis without transforming the data. Bin count is 10 ha. Bars represent the percentage of total records smaller than the mean (95\%) and median areas (49\%). R version 3.4.2.

As noted in their metadata, PADUS is subject to errors of omission and commission. Some of the errors they report are due to overlap-topology—and they mention "slivers" specifically. We observed that some of the smallest polygons in the dataset were geoprocessing artifacts, including slivers [11]. These were typically very small, but the smallest records in the PADUS were a relatively minor portion. For example, $2.4 \%$ are $<0.1$ ha in size. On the other hand, many very small polygons are legitimate 
conserved parcels. Many records (27,338 or 14.1\%) were less than 1 ha and distinct parcels, as illustrated in Figure 3. While many of the small records have attributes indicating they are conservation easements or small parks, others may not be real or their spatial attributes may be inaccurate; investigating the characteristics of these parcels is an important research question, because while most are conserved areas, others may have inaccurate spatial information and influence the size distribution. Another source of error could be lack of clarity over what constitutes a separate protected area in an ownership sense, as distinct from a polygon sense. For example, the database has some records that are split polygons, so that one continuous protected area is represented by two records.

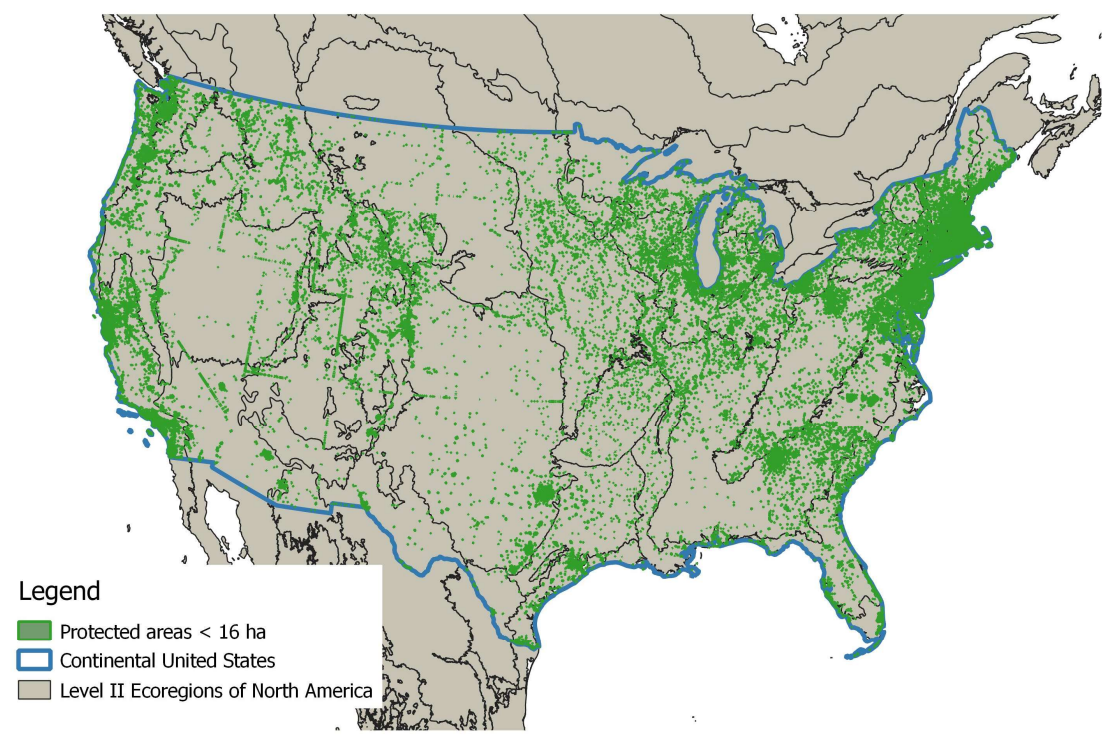

Figure 2. Small protected areas distributed across the continental United States. Shown in green on the map are the protected areas $<16 \mathrm{ha}$, which is the median parcel size for the area shown. Data from PADUS V1.4 Combined Feature Class. QGIS V3.2.

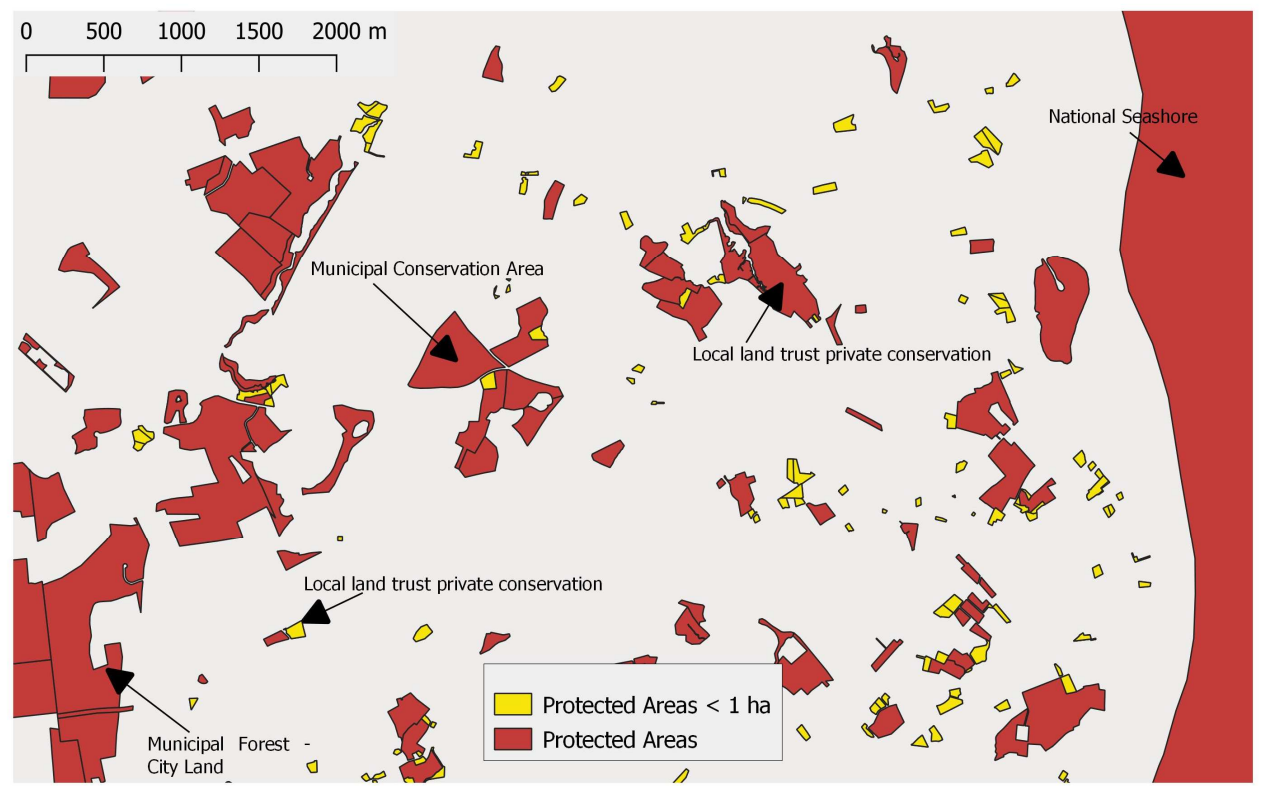

Figure 3. A portion of Cape Cod, USA, showing extremely small conserved parcels $<1$ ha, in yellow, in a matrix of slightly larger projects typical of those discussed in this paper. A selection of parcels is labeled to show the types of conservation lands in this landscape. Even the $<1$ ha areas have "conservation" designations in the database, i.e., are not data anomalies. To what extent small protected areas perform landscape-level biodiversity functions is largely unknown. QGIS V 3.2. 
The PADUS is a massive undertaking managing hundreds of thousands of polygons generated by a plethora of sources, and errors are to be expected. The PADUS metadata states that the project reports spatial data as they are received. A thorough study of the PADUS should quantify the extent of errors, how they may influence analyses, compare representation of small areas in the PADUS with other protected areas datasets such as the World Database on Protected Areas (WDPA), and investigate spatial and designation rules for how distinct protected areas are defined.

Since the PADUS is built from contributions from states and others who keep public land records, and relies on voluntary submission for private areas, it is probably incomplete. There is evidence that it disproportionately underrepresents smaller parcels. The National Conservation Easement Database (NCED 2018) has more conservation easements recorded for the Continental US than does PADUS. NCED contains over 158,168 records, while in the continental PADUS, only 54,590 are categorized as easements. According to its documents, the NCED itself is incomplete. It relies on voluntary submission by land trusts, many of whom do not want to share to a large public database due to privacy and other concerns [12]. More research is needed on the structure of datasets that serve spatial data on protected areas in regards to smaller areas, and errors of commission and omission, before a firm knowledge of size distribution of protected areas can be obtained, and this needs to be undertaken on a global scale [13].

\section{What Is "Small"?}

For this review, we consider "small" based on the observed distribution in the PADUS. A "small protected area" is at the lower end of the range, between 16 ha (the US median) and 1648 ha (the US mean) in size. By this definition, then, small areas would be from tens to hundreds of hectares in size, rather than thousands of hectares. Areas in the range of tens to hundreds of hectares are often the focus of local conservation projects (Figures 3 and 4 ).

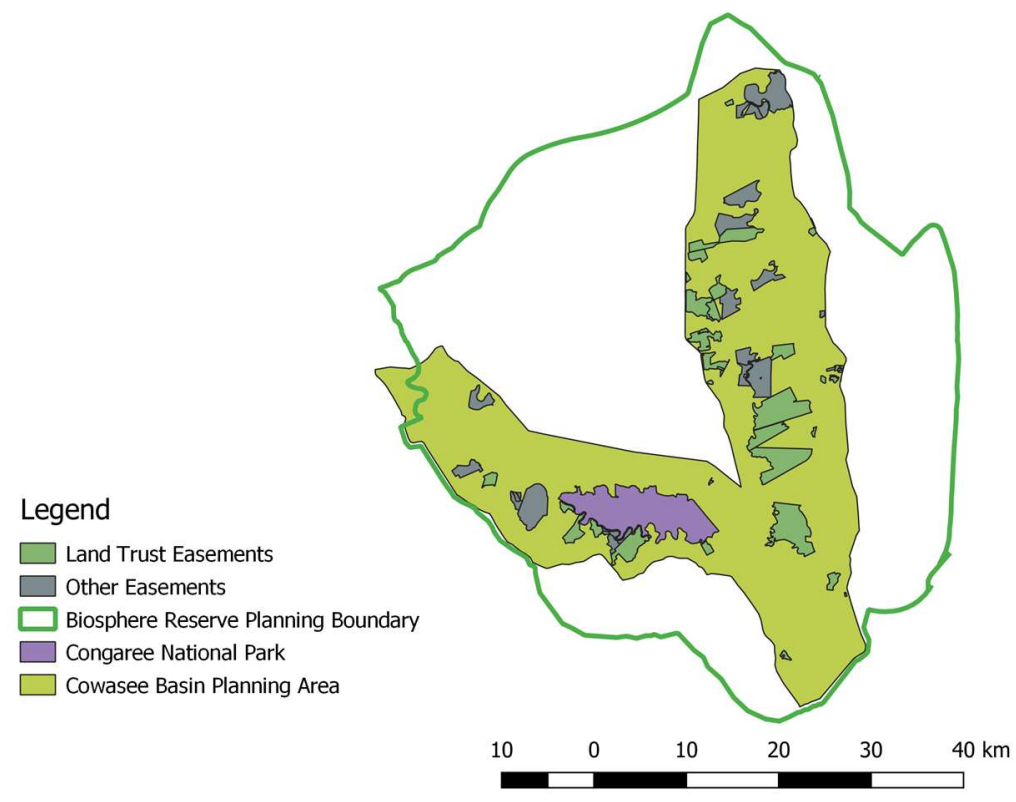

Figure 4. A landscape in South Carolina, USA showing small conservation lands within two overlapping planning projects, an International Biosphere Reserve, and the COWASEE Basin Task Force. Conservation actions within these areas are coordinated to meet landscape-level objectives. QGIS V3.2.

Figure 4 shows the Congaree-Wateree River region of South Carolina, USA. Numerous conserved parcels ranging from 4 to 6179 ha in size are represented, established by public and private entities for conservation purposes. Also shown are two overlapping planning areas illustrating landscape context 
as mentioned below. This is an example of a landscape in which there are many small protected areas, and in which ecosystem management and systematic conservation planning are practiced, to a degree.

\section{Potential Importance of Small Areas}

Considerable cost is incurred in establishing and managing small protected areas [14]. Aside from their sheer number and costs of acquisition, smaller areas may cost more to manage than larger ones due to the challenges of having management tasks distributed. On the other hand, smaller areas arise from local concerns and may serve local purposes better than larger, more distant areas. Small parks and private conserved lands are typically generated and managed at the local scale-as in counties, states, cities, land trusts, landowners, and indigenous people. These include the bulk of conservation easements, local parks, historical and archaeological sites, private reserves, wildlife refuges, and community forests $[15,16]$. One drawback is that some would not be considered by international bodies to be areas whose primary purpose is biodiversity conservation. If they maintain natural land cover and are unable to be developed, they nonetheless function to exclude conversion to development. Furthermore, they often have specific conservation goals, and these include those related to biodiversity $[17,18]$.

Despite their prevalence and potential benefit, there is very little known about how smaller protected areas function to provide biodiversity protection that may complement large, public protected areas and help address global issues $[19,20]$. The abundance of small protected areas-at least in the continental United States-underscores the need for a better understanding of their collective and individual function and how future conservation efforts may be oriented towards achieving larger landscape goals. Unfortunately, the literature on these issues is not robust. Much research on small protected areas remains to be done and applied to conservation planning, design, acquisition, and management.

\section{Landscape-Level Views of Small Areas}

A large body of literature shows that as islands of habitat become smaller and more isolated, they lose local populations of species [21]. Parks and protected areas, when fragments of larger once-connected landscapes, follow these island-biogeographic trends [22]. Ecological isolation increases if the conserved area is in a matrix of intensive land uses decreasing permeability and dispersal opportunities and increasing edge penetration to the core [6]. As a consequence, smaller areas in human-dominated matrices with intensive land uses are expected to have reduced biodiversity conservation function than larger, more well-connected areas.

As a whole, perhaps because of the importance of large size, the literature on protected areas is focused on those that are the largest. For example, globally protected areas are biased towards locations where they will have the least effect of reducing land conversion [4]. That study, and many others like it, investigate the coarse-scale pattern using minimum grain sizes of $1 \mathrm{~km}^{2}$ or greater. The number and types of studies focusing on the smallest areas appears to be increasing, and the potential importance of grassroots conservation, private land, and multiscale conservation becomes more evident [23]. In the United States, the rapid increase in the number of conservation easements has given rise to studies of their effectiveness $[19,24]$. There are many state and county parks which may provide meaningful habitat protection. For example, the life histories of some wetland animals may be accommodated by protected areas considered to be small, as in state parks in the hundreds of hectares range [25]. Others have focused on how the scale of conservation can fit the scale of the ecosystem, community, policy environment, or process of concern [26]. Vernal pool systems in the Northeastern United States may be significantly protected by local conservation actions [27]. In some parts of the world, community-owned and managed forests are localized socioecological systems that may have greater conservation outcomes and more local support than traditional protected areas [15].

Studies focused on how populations and communities function across time and space provide insight into how small protected areas may function and how their internal processes may be influenced 
by events occurring outside their boundaries. Populations and communities are not isolated in space; conditions at a varying distances can influence response variables such as occupancy, population size, and community composition and structure at a site [28,29]. Dispersal and migration are common foci of these studies, as they are mechanisms connecting populations, and can provide insight into how to design conservation landscapes. Some of these movements, such as for reptiles and amphibians, are highly local in scale (e.g., hundreds of meters), yet still require landscape-level thinking for conservation purposes [30]. In fact, using landscape-level analyses to configure habitats in conservation plans at local scales for pond-breeding amphibians has been a productive area of research [31,32]. Small protected areas may be important for climate change adaptation, such as when considering the need to provide habitats during range shifts through human-dominated landscapes [33].

Studies that incorporate multiple spatial scales may help a manager of a small parcel to understand how the management of adjacent properties within specified distances influences conditions observed at the site. For example, forest cover is important at certain thresholds and distances [34], loss of wetland density at landscape scales influences local diversity [35], butterfly metapopulations depend on a spatially and temporally dynamic system of habitat patches [36], and turtles follow an array of routes over large areas and are strongly influenced by road traffic within that landscape [37]. A small reserve may have wildlife populations that may be perceived as resident, but routinely exchange wildlife with surrounding properties.

Some small protected areas serve very specific and well-known functions in a process that covers a much larger area. For example, bird migratory stopovers and seabird breeding sites are very spatially specific, and small protected areas have been established to cover those functions. Cape May, New Jersey, is a place where waterfowl, raptors, shorebirds, and songbirds congregate during spring migration [38]. Cape May National Wildlife Refuge is about 4900 ha in size and is a key location in the Atlantic Flyway. L'île Bonaventure-et-du-Rocher Percé in eastern Canada was protected in 1919 as a 1361-ha Migratory Bird Sanctuary, hosting thousands of breeding pairs of seabirds, including about half of the Northern Gannets breeding in the Atlantic [39]. The Western Hemisphere Shorebird Reserve Network has collated information on 102 locations with sizes ranging from several hundred to tens of thousands of hectares from the tip of South America to Alaska, and provides scientific resources to aid in their conservation (https:/ / www.whsrn.org/).

When small protected areas are embedded in human-dominated landscapes, they are more susceptible to ecological isolation than larger protected areas in those same areas. Urbanization creeps out from metropolitan areas and causes rural lands to transition to higher density residential landscapes with attendant roads, industries, and services [40]. Land values rise during this process, and while there may be more funds and incentives available for conservation deals on private land, these deals are competing with the real estate market [41]. Consequently, most land transitions in the United States are from rural to residential, resulting in the increased isolation of the remaining natural lands. At the same time, small conservation areas embedded in urbanizing areas may provide disproportionately high conservation values [42] and benefits for human health and wellbeing [43].

\section{Ecosystem Management for Small Areas}

Ecosystem management is a way of organizing thinking about individual protected areas and private parcels in relation to the spatial and temporal scales at which ecosystem processes occur, as opposed to within political or jurisdictional boundaries. Its management roots were in the Pacific Northwest in the late 20th century, where there were significant endangered species management issues and social conflicts resulted [44]. Accommodating dispersal, gene flow, disturbance, migration, and other ecological processes requires working across management units, ownerships, and jurisdictions. For example, conserving migratory movements of ungulates may be dependent on highly localized natural features that occur outside protected areas, practices of landowners such as fencing, differing game laws across political boundaries, and departments of transportation who are 
responsible for wildlife underpasses and overpasses [45,46]. Such tasks will be more challenging in landscapes where there are lots of smaller areas.

Natural disturbance regimes help to maintain biological diversity, but are difficult to manage across boundaries of protected areas [47]. Managing a landscape-level disturbance, such as fire, is a challenge for protected areas as neighboring landowners are influenced. Because of perimeter-to-area ratios, such boundary-related tasks will be more difficult the smaller the protected area is. Nonetheless, fire management is frequently practiced on small reserves. For example, even in the urban setting of the Hitchcock Woods in South Carolina ( $850 \mathrm{ha})$, the longleaf pine systems are maintained by repeated burning. Much education is undertaken with local residents. However, knowledge of how to manage fire in local socioeconomic systems is rarely published [48]. Thus, there is much more knowledge available than is in present in the scientific literature and can be accessed via websites, workshops, and so on. Smaller protected areas may be vulnerable to large disturbances, as a hurricane or pathogen could wipe out a large percentage of its contents. For example, old growth forests on a 2180-ha portion of the Cape Romain National Wildlife Refuge in South Carolina were decimated-for one pine species, almost total losses-after Hurricane Hugo in 1989 [49]. The smaller the protected area, the more likely a single disturbance event will change the entire ecosystem. If this happens to a small protected area that is isolated by development, problems are compounded.

Ecosystem management may be more important for smaller protected areas due to their isolation and abundance and complexities of ownerships. A landscape with many protected areas with different managers and owners is a challenge in cross-boundary cooperation [50]. For one thing, smaller areas are more likely to have ecological processes that transcend boundaries. One approach to cooperation, examined for two very small parcels, was to identify the owners responsible for landscape features important to ecosystem function, and then develop a plan for the neighbors to accommodate movements of animals using habitats on each parcel. Such an approach required mutual understanding of the ecological and conservation issues and agreement on values [51]. Another example is the Southern Low Country ACE Basin longleaf partnership that manages the longleaf system which involves frequent burning (https:/ / www.longleafalliance.org/soloace).

The region shown in Figure 4 has two overlapping planning areas: an International Biosphere Reserve and a landscape-level alliance or Task Force. Both planning areas share members, for example, from the National Park Service, Congaree Land Trust, and state agencies. The idea is to increase cooperation to achieve landscape-level conservation goals. The hope is that even though the protected areas are small, their collective impact may be increased by better management of un-conserved lands, while preserving local resource-based economies. Similarly, community conserved areas (CCAs) are a global phenomenon that provide biodiversity services while satisfying the needs of local and indigenous peoples. They are not very well understood in terms of their overall contributions to biodiversity conservation, but due to their extensive coverage (as much as $11 \%$ of global forests), are an example of how relatively small, local projects can accumulate effects [52]. These approaches can be facilitated by landscape-level cooperatives and alliances, especially if they respect human dimensions. For example, in governance of conservation networks, recognizing and trading leadership roles based on what is needed to accomplish particular goals is better than traditional, top-down management [53].

\section{Systematic Conservation Planning for Small Areas}

Systematic conservation planning is a rapidly growing field in spatial ecology that attempts to allocate conservation actions across the landscape based on patterns of representation, size and configuration, and threat [54]. Systematic conservation planning uses spatial datasets in complex, mathematically-driven layering operations to identify which parts of the landscape meet conservation goals. Many spatially extensive analyses and localized projects have been completed, such as that presented in [55]. One of the weaknesses of conservation planning is the lack of relevance to local decision-making when there is a mismatch between grain size and data quality and the scale at which decision-makers need information [56,57]. 
Local conservationists seeking to prioritize small parcels may not be able to develop models comparable to those produced at greater spatial extents. Spatial data is often less available at the fine grain sizes relevant to local conservation than at the coarse grain sizes relevant for large-landscape projects, resulting in maps and models for systematic planning that show broad patterns, but are less relevant locally. Biodiversity data may consist of points with high accuracy, but the coverage of points is often nonuniform and biased towards survey routes or other observation patterns. Resulting species distribution maps, which are often the basis for conservation plans, are influenced by these data limitations [58]. Smaller conservation organizations often do not have the technical capacity or funding to invest in new, fine-grain data for spatial planning. Even if they engage in systematic conservation planning, and many do, they are forced to use coarser-grain data. Grain size and extent of analysis can influence model results, resulting in locations prioritized for conservation that are influenced by the accuracy of the data [59]. Resolving questions of scale is an important area of research if spatial conservation planning is to be relevant for the smallest protected areas.

Despite these challenges, systematic conservation planning has the potential to greatly improve the biodiversity impact of new small protected areas. Until the advent of these methods, many conservation projects were focused on protecting single populations of rare and endemic plants and particular ecosystems (e.g., cliffs and caves), regardless of spatial context. The Nature Conservancy is one of the largest private conservation organizations in the world. It is a leader in conservation planning, yet has numerous smaller reserves in the US that represent an occurrence of a rare species or important localized ecosystem. Their Places We Protect website provides background information on these, for example, the 202-ha Loverens Mill Cedar Swamp in New Hampshire (https: //www.nature.org/en-us/get-involved/how-to-help/places-we-protect/). The Nature Conservancy was a leader in forming the field of systematic conservation planning, attempting to "scale up" from their site-based approach to larger and more connected areas [60]. Their approach now integrates the small, important sites with landscape-level patterns and processes, focused on resilience to climate change [61].

Given the preponderance of small protected areas, those engaged in systematic conservation planning may need to be more focused on how to improve site selection at the local scale. It appears that at least in some areas of the United States, land trusts and others in conservation are protecting many areas that are close to where they live and work [20]. It is unclear to what degree these decisions are being driven by spatial conservation priorities, or by opportunities and aesthetics, and local knowledge about site conditions.

Initiating more systematic conservation planning at local scales for small areas will necessitate better databases that are more fine-scale. Since land use and land cover data are the basis of most conservation planning models, developing more localized land cover data should be a top priority [62]. Fine-scale biodiversity data can be improved through USGS GAP species distribution models, the Global Biodiversity Information Facility (GBIF), and proprietary sources such as NatureServe. As stated earlier, more complete representation of very small areas in protected areas databases including PADUS, NCED, and the World Database on Protected Areas (WDPA) will help.

Local land use decision-making usually occurs in the context of development, but conservation planners can get involved and bring biodiversity concerns into that context [63]. Such planning projects should be done within a spatially hierarchical framework (e.g., landscapes-ecoregions), so that what is accomplished locally will have relevance when viewed in greater spatial contexts. Larger regional analyses may point to localities that have biodiversity importance at an ecoregional level (e.g., species geographic ranges, across climate gradients, and large land use transitions). Within those localities prioritized as being important at a coarser-grain level, local conservation groups should plan using finer-grained data. Funding agencies should recognize that planning and data development require support at every scale. 


\section{Summary}

More research is needed on the spatial distribution and landscape-level functions of small protected areas. At least in the United States, small areas dominate the frequency distribution and may have greater collective impact on conservation than their individual sizes suggest. Larger areas still account for most of the coverage, but their function may be enhanced by a matrix-improving impact of small sites, which may also serve to represent localized natural phenomena. Scattered across the landscape at varying densities, small areas may provide landscape-level functions that enhance biodiversity conservation. Better landscape-level management and planning at local scales could improve their current function and spatial distribution of additional areas. Datasets are incomplete and may have inaccuracies, so should be improved so that the above hypotheses may be tested.

Considerable effort is expended to protect and manage small areas, but not enough is known about how they contribute to global biodiversity goals. Even the smallest protected areas may protect localized ecosystems, collectively improve landscape-level conditions such as permeability and matrix quality, and may be important to human community health and wellbeing. While systematic conservation planning has made great scientific strides and is being applied at most scales, data availability and accuracy, financial restrictions, and lack of access to technology may limit its application to small projects. More research and data development are needed to ensure that the cumulative effect of small areas is a net gain for global biodiversity conservation.

\subsection{Recommendations for Research}

- Examine effects of small protected areas on landscape-level patterns and processes, including local representation of regional diversity, improvement of matrix quality, metapopulation and community services, stopover sites, and network centrality.

- Examine protected areas dataset completeness and topology errors for small areas.

- Develop fine-grain biological and economic data to be used in local-scale systematic conservation planning.

- Examine social and economic barriers that keep partners who own, manage, or monitor small protected areas-e.g., land trusts, local governments, indigenous peoples-from participating in larger landscape efforts.

- Conduct economic research on contributions of small areas to ecosystem services, including water purification and supply, biodiversity, and flood storage.

- Research how small protected areas may contribute to resiliency following large-scale disturbances and contribute to climate change adaptation.

- Examine role of small protected areas in local communities and how they contribute to social, physical, and psychological health and wellbeing.

\subsection{Recommendations for Management}

- Manage for ecosystem processes such as dispersal and disturbance that extend outside property boundaries.

- Identify the neighboring landowners that accommodate ecosystem processes influencing the site; collaborate across boundaries.

- Provide mapped data on small areas to public databases so it can be used in conservation planning.

- Contribute time and resources to protecting other parcels in your landscape to form functional networks.

- Participate in watershed-level activities to enhance water quality.

- Participate in large landscape efforts to restore natural disturbance regimes.

- Scale up: represent the locality in larger landscape conservation efforts.

- Educate stakeholders about the importance of participating in larger efforts. 
Author Contributions: Conceptualization, R.F.B.; Methodology, R.F.B. and N.F.; Software, R.F.B. and N.F.; Formal Analysis, R.F.B. and N.F.; Data Curation, R.F.B.; Writing-Original Draft Preparation, R.F.B.; Writing-Review \& Editing, R.F.B. and N.F.; Visualization, R.F.B. and N.F.; Supervision, R.F.B.; Funding Acquisition, R.F.B.

Funding: This research was funded by The National Science Foundation, grant number 1518455, and the Margaret H. Lloyd-SmartState Endowment for South Carolina.

Acknowledgments: We thank Congaree Land Trust, Congaree National Park, Cowasee Basin Task Force, the Department of Forestry and Environmental Conservation at Clemson University, and colleagues on the Clemson-Conservation Easement project (NSF 1518455) for their support.

Conflicts of Interest: The authors declare no conflict of interest.

\section{References}

1. Noss, R.F.; Dobson, A.P.; Baldwin, R.F.; Beier, P.; Davis, C.R.; dellaSala, D.A.; Francis, J.; Locke, H.; Nowak, K.; Lopez, R.; et al. Bolder thinking for conservation. Conserv. Boil. 2012, 26, 1-4. [CrossRef] [PubMed]

2. Margules, C.R.; Pressey, R.L. Systematic conservation planning. Nature 2000, 405, 243-253. [CrossRef] [PubMed]

3. Jenkins, C.N.; Van Houtan, K.S.; Pimm, S.L.; Sexton, J.O. US protected lands mismatch biodiversity priorities. Proc. Natl. Acad. Sci. USA 2015, 112, 5081-5086. [CrossRef] [PubMed]

4. Joppa, L.N.; Pfaff, A. High and far: Biases in the location of protected areas. PLoS ONE 2009, 4, e8273. [CrossRef] [PubMed]

5. DeFries, R.; Karanth, K.K.; Pareeth, S. Interactions between protected areas and their surroundings in human-dominated tropical landscapes. Boil. Conserv. 2010, 143, 2870-2880. [CrossRef]

6. Woodroffe, R.; Ginsberg, J.R. Edge effects and the extinction of populations inside protected areas. Science 1998, 280, 2126-2128. [CrossRef] [PubMed]

7. Powell, R.B.; Cuschnir, A.; Peiris, P. Overcoming governance and institutional barriers to integrated coastal zone, marine protected area, and tourism management in Sri Lanka. Coast. Manag. 2009, 37, 633-655. [CrossRef]

8. McRae, B.H.; Hall, S.A.; Beier, P.; Theobald, D.M. Where to restore ecological connectivity? Detecting barriers and quantifying restoration benefits. PLoS ONE 2012, 7, e52604. [CrossRef] [PubMed]

9. Gurney, G.G.; Pressey, R.L.; Ban, N.C.; Álvarez-Romero Jorge, G.; Jupiter, S.; Adams, V.M. Efficient and equitable design of marine protected areas in Fiji through inclusion of stakeholder-specific objectives in conservation planning. Conserv. Boil. 2015, 29, 1378-1389. [CrossRef] [PubMed]

10. USGS. Protected Areas Database of the United States (PAD-US), Version 1.4 Combined Feature Class; U.S. Department of the Interior: U.S. Geological Survey, 2016.

11. Lipscomb, D.J.; Baldwin, R.F. Geoprocessing solutions developed while calculating Human Footprint statistics for zones representing protected areas and adjacent lands at the continent scale. Math. Comput. For. Nat. Resour. Sci. 2010, 2, 72-78.

12. Rissman, A.R.; Owley, J.; L'Roe, A.W.; Morris, A.W.; Wardropper, C.B. Public access to spatial data on private-land conservation. Ecol. Soc. 2017, 22, 24. [CrossRef]

13. Clements, H.; Selinske, M.; Archibald, C.; Cooke, B.; Fitzsimons, J.; Groce, J.; Torabi, N.; Hardy, M. Fairness and Transparency Are Required for the Inclusion of Privately Protected Areas in Publicly Accessible Conservation Databases. Land 2018, 7, 96. [CrossRef]

14. Armsworth, P.R.; Cantú-Salazar, L.; Parnell, M.; Davies, Z.G.; Stoneman, R. Management costs for small protected areas and economies of scale in habitat conservation. Boil. Conserv. 2011, 144, 423-429. [CrossRef]

15. Porter-Bolland, L.; Ellis, E.A.; Guariguata, M.R.; Ruiz-Mallén, I.; Negrete-Yankelevich, S.; Reyes-García, V. Community managed forests and forest protected areas: An assessment of their conservation effectiveness across the tropics. For. Ecol. Manag. 2012, 268, 6-17. [CrossRef]

16. Brewer, R. Conservancy: The Land Trust Movement in America; Dartmouth College, University of Press of New England: Hanover, NH, USA, 2003; p. 364.

17. Dudley, N.; Parrish, J.D.; Redford, K.H.; Stolton, S. The revised IUCN protected areas management categories: The debate and ways forward. Oryx 2010, 44, 485-490. [CrossRef]

18. Merenlender, A.M.; Huntsinger, L.; Guthey, G.; Fairfax, S.K. Land trusts and conservation easements: Who is conserving what for whom? Conserv. Boil. 2003, 18, 65-75. [CrossRef] 
19. Rissman, A.R.; Merenlender, A.M. The conservation contributions of conservation easements: Analysis of the San Francisco Bay Area Protected Lands Database. Ecol. Soc. 2008, 13, 25. [CrossRef]

20. Baldwin, R.F.; Leonard, P.B. Interacting social and environmental predictors for the spatial distribution of conservation lands. PLoS ONE 2015, 10, e0140540. [CrossRef] [PubMed]

21. Hunter, M.L.; Gibbs, J.P. Fundamentals of Conservation Biology, 3rd ed.; Blackwell Publishing: Oxford, UK, 2007.

22. Newmark, W.D. Extinction of mammal populations in Western North American National Parks. Conserv. Boil. 1995, 9, 512-526. [CrossRef]

23. Hilty, J.; Merenlender, A.M. Studying biodiversity on private lands. Conserv. Boil. 2003, 17, $132-137$. [CrossRef]

24. Kiesecker, J.M.; Comendant, T.; Grandmason, E.; Gray, E.M.; Hall, C.; Hilsenbeck, R.; Kareiva, P.; Lozier, L.; Naehu, P.; Rissman, A.R.; et al. Conservation easements in context: A quantitative analysis of their use by The Nature Conservancy. Front. Ecol. Environ. 2007, 5, 125-130. [CrossRef]

25. Pitt, A.L.; Howard, J.H.; Baldwin, R.F.; Baldwin, E.D.; Brown, B.L. Small Parks as Local Social-Ecological Systems Contributing to Conservation of Small Isolated and Ephemeral Wetlands. Nat. Areas J. 2018, 38, 237-249. [CrossRef]

26. Calhoun, A.J.K.; Jansujwicz, J.S.; Bell, K.P.; Hunter, M.L. Improving management of small natural features on private lands by negotiating the science-policy boundary for Maine vernal pools. Proc. Natl. Acad. Sci. USA 2014, 111, 11002-11006. [CrossRef] [PubMed]

27. Hunter, M.L. Valuing and conserving vernal pools as small-scale ecosystems. In Science and Conservation of Vernal Pools in Northeastern North America; Calhoun, A.J.K., deMaynadier, P.G., Eds.; CRC Press: New York, NY, USA, 2008; pp. 1-10.

28. Hanski, I. Metapopulation dynamics. Nature 1998, 396, 41-49. [CrossRef]

29. Leibold, M.A.; Holyoak, M.; Mouquet, N.; Amarasekare, P.; Chase, J.M.; Hoopes, M.F.; Holt, R.D.; Shurin, J.B.; Law, R.; Tilman, D.; et al. The metacommunity concept: A framework for multi-scale community ecology. Ecol. Lett. 2004, 7, 601-613. [CrossRef]

30. Semlitsch, R.D. Differentiating migration and dispersal processes for pond-breeding amphibians. J. Wildl. Manag. 2008, 72, 260-267. [CrossRef]

31. Compton, B.W.; McGarigal, K.; Cushman, S.A.; Gamble, L. A resistant-kernal model of connectivity for amphibians that breed in vernal pools. Conserv. Boil. 2007, 21, 788-799. [CrossRef] [PubMed]

32. Harper, E.B.; Rittenhouse, T.A.G.; Semlitsch, R.D. Demographic consequences of terrestrial habitat loss for pool-breeding amphibians: Predicting extinction risks associated with inadequate size of buffer zones. Conserv. Boil. 2008, 22, 1205-1215. [CrossRef] [PubMed]

33. Nuñez, T.; Lawler, J.J.; McRae, B.H.; Pierce, D.J.; Krosby, M.R.; Kavanagh, D.M.; Singleton, P.H.; Tewksbury, J.J. Connectivity planning to facilitate species movements in response to climate change. Conserv. Boil. 2013, 27, 407-416. [CrossRef] [PubMed]

34. Homan, R.N.; Windmiller, B.S.; Reed, J.M. Critical thresholds associated with habitat loss for two vernal pool-breeding amphibians. Ecol. Appl. 2004, 14, 1547-1553. [CrossRef]

35. Gibbs, J.P. Importance of small wetlands for the persistence of local populations of wetland-associated animals. Wetlands 1993, 13, 25-31. [CrossRef]

36. Hanski, I.; Thomas, C.D. Metapopulation dynamics and conservation: A spatially explicit model applied to butterflies. Boil. Conserv. 1994, 68, 167-180. [CrossRef]

37. Beaudry, F.; deMaynadier, P.G.; Hunter, M.L. Identifying road mortality threat at multiple spatial scales for semi-aquatic turtles. Boil. Conserv. 2008, 141, 2550-2563. [CrossRef]

38. Niles, L.J.; Burger, J.; Clark, K.E. The Influence of Weather, Geography, and Habitat on Migrating Raptors on Cape May Peninsula. Condor 1996, 98, 382-394. [CrossRef]

39. Chardine, J.W.; Rail, J.-F.; Wilhelm, S. Population dynamics of Northern Gannets in North America, 1984-2009. J. Field Ornithol. 2013, 84, 187-192. [CrossRef]

40. Theobald, D.M. Placing exurban land-use change in a human modification framework. Front. Ecol. Environ. 2004, 2, 139-144. [CrossRef]

41. Bell, K.P.; Irwin, E.G. Spatially explicit micro-level modelling of land use change at the rural-urban interface. Agric. Econ. 2002, 27, 217-232. [CrossRef]

42. Baldwin, R.F.; deMaynadier, P.G. Assessing threats to pool-breeding amphibian habitat in an urbanizing landscape. Boil. Conserv. 2009, 142, 1628-1638. [CrossRef] 
43. Larson, L.R.; Jennings, V.; Cloutier, S.A. Public parks and wellbeing in urban areas of the United States. PLoS ONE 2016, 11, e0153211. [CrossRef] [PubMed]

44. Grumbine, R.E. What is ecosystem management? Conserv. Boil. 1994, 8, 27-38. [CrossRef]

45. Berger, J. The last mile: How to sustain long-distance migration in mammals. Conserv. Boil. 2004, 18, 320-331. [CrossRef]

46. Trombulak, S.C.; Frissell, C.A. Review of ecological effects of roads on terrestrial and aquatic communities. Conserv. Boil. 2000, 14, 18-30. [CrossRef]

47. Baker, W.L. The landscape ecology of large disturbances in the design and management of nature reserves. Landsc. Ecol. 1992, 7, 181-194. [CrossRef]

48. Neel, L. The Art of Managing Longleaf; University of Georgia Press: Athens, GA, USA, 2010; p. 211.

49. Conner, W.H.; Mixon, W.D.; Wood, G.W. Maritime forest habitat dynamics on Bulls Island, Cape Romain National Wildlife Refuge, SC, following Hurricane Hugo. For. Ecol. Manag. 2005, 212, 127-134. [CrossRef]

50. Chester, C.C. Conservation across Borders: Biodiversity in an Interdependent World; Island Press: Washington, DC, USA, 2006.

51. Colbert, N.; Baldwin, R.F. A developer-initiated conservation plan for pool-breeding amphibians in Maine, USA: A case study. J. Conserv. Plan. 2011, 7, 27-38.

52. Kothar, A. Community conserved areas: Towards ecological and livelihood security. Parks 2006, 16, 3-13.

53. Imperial, M.T.; Ospina, S.; Johnston, E.; O’Leary, R.; Thomsen, J.; Williams, P.; Johnson, S. Understanding leadership in a world of shared problems: Advancing network governance in large landscape conservation. Front. Ecol. Environ. 2016, 14, 126-134. [CrossRef]

54. Baldwin, R.F.; Trombulak, S.C.; Leonard, P.B.; Noss, R.F.; Hilty, J.A.; Possingham, H.P.; Scarlett, L.; Anderson, M.G. The Future of Landscape Conservation. BioScience 2018, 68, 60-63. [CrossRef] [PubMed]

55. Leonard, P.; Baldwin, R.F.; Hanks, D. Landscape-scale conservation design across biotic realms: Sequential integration of aquatic and terrestrial landscapes. Sci. Rep. 2017, 7, 14556. [CrossRef] [PubMed]

56. Guerrero, A.M.; McAllister, R.R.J.; Corcoran, J.; Wilson, K.A. Scale Mismatches, Conservation Planning, and the Value of Social-Network Analyses. Conserv. Boil. 2013, 27, 35-44. [CrossRef] [PubMed]

57. Theobald, D.M.; Spies, T.; Kline, J.D.; Maxwell, B.; Hobbs, N.T.; Dale, V.H. Ecological support for rural land-use planning. Ecol. Appl. 2005, 15, 1906-1914. [CrossRef]

58. Franklin, J. Mapping Species Distributions: Spatial Inference and Prediction; Cambridge University Press: Cambridge, UK, 2009; p. 320.

59. Leonard, P.B.; Duffy, E.B.; Baldwin, R.F.; McRae, B.H.; Shah, V.B.; Mohapatra, T.K. GFLOW: Software for modelling circuit theory-based connectivity at any scale. Methods Ecol. Evol. 2017, 8, 519-526. [CrossRef]

60. Groves, C.; Jensen, D.; Valutis, L.L.; Redford, K.H.; Shaffer, M.; Scot, J.M.; Baumgartner, J.V.; Higgins, J.V.; Beck, M.W.; Anderson, M.G. Planning for biodiversity conservation: Putting conservation science into practice. Bioscience 2002, 52, 499-512. [CrossRef]

61. Anderson, M.G.; Clark, M.; Sheldon, A.O. Estimating climate resilience for conservation across geophysical settings. Conserv. Boil. 2014, 28, 959-970. [CrossRef] [PubMed]

62. Theobald, D. A General-Purpose Spatial Survey Design for Collaborative Science and Monitoring of Global Environmental Change: The Global Grid. Remote Sens. 2016, 8, 813. [CrossRef]

63. Theobald, D.M.; Hobbs, R.J.; Bearly, T.; Zack, J.A.; Shenk, T.; Riebsame, W.E. Incorporating biological information in local land-use decision-making: Designing a system for conservation planning. Landsc. Ecol. 2000, 15, 35-45. [CrossRef]

(C) 2018 by the authors. Licensee MDPI, Basel, Switzerland. This article is an open access article distributed under the terms and conditions of the Creative Commons Attribution (CC BY) license (http:/ / creativecommons.org/licenses/by/4.0/). 